\title{
Beta-Thioguanine Deoxyriboside
}

National Cancer Institute

\section{Source}

National Cancer Institute. Beta-Thioguanine Deoxyriboside. NCI Thesaurus. Code C1350.

A thiopurine nucleoside derivative with antineoplastic activity. After conversion to the triphosphate, beta-thioguanine deoxyriboside is incorporated into DNA, resulting in inhibition of DNA replication. This agent is cytotoxic against leukemia cell lines and has demonstrated some activity against leukemia cells in vivo. Beta-thioguanine deoxyriboside demonstrates antineoplastic activity against 6-thioguanine-resistant tumor cells. ( $\mathrm{NCl04)}$ 